\title{
Assessing The Impact of Shallow Groundwater on Soil Salinity and Biomass Yield of Plants Grown in North Nile Delta Using Remote Sensing and GIS
}

\author{
M.M. Amer ${ }^{*}$ H.M. Aboelsoud, E.H.Omar and M.G. Zoghdan \\ Soils, Water \& Environment Research Institute, Agric. Res. Centre (ARC), Giza, Egypt
}

\begin{abstract}
$\mathbf{T}$
HIS STUDY was conducted to evaluate soil salinity distribution and biomass yield as affected by shallow groundwater (GW) in North Delta by employing GIS and remote sensing. The ground water depth (GWD) in the investigated area is mainly affected by the drainage system status. Thus, GWD was measured by automatic sensors and ranged between 80 and $130 \mathrm{~cm}$ based on the performance status of the tile drainage collectors. The drawdown rate (DDR) of GW decreased rapidly by time, due to the poor structured soil. DDR was 18.5-45.1 $\mathrm{cm} /$ day through the $1 \mathrm{st} 24 \mathrm{hr}$ after irrigation, then decreased to $14.6-31.2 \mathrm{~cm} /$ day through the $1 \mathrm{st} 48 \mathrm{hr}$, while it recorded $6.2-10.1 \mathrm{~cm} /$ day through the duration time (DT) which is the time for GW to reach the deepest level after irrigation. The DT is inversely proportional to the DDR and their values are related mainly to the efficiency of the drainage system and soil properties. So, the shallowest GW was recorded with the relative long DT and slow DDR and vice versa.A significant negative correlation was obtained between soil ECe,determined by EM38, and GWD $(\mathrm{R} 2=0.576)$. Consequently, the soils of the part in the studied area suffers from shallow GW $(81 \mathrm{~cm})$ having ECe $(6.8 \mathrm{dS} / \mathrm{m})$ higher than that in other parts, while the lowest ECe $(4.6 \mathrm{dS} / \mathrm{m})$ was found in the part which has deeper $\mathrm{GW}(125 \mathrm{~cm})$. A positive weak correlation was observed between biomass yield and GWD $(\mathrm{R} 2=0.55)$, whereas its correlation with root zone ECe was significant and negative $(\mathrm{R} 2=0.68)$. The yield potential in parts with relative low EC soils (4.6$4.9 \mathrm{dS} / \mathrm{m})$ was about $10 \%$ higher than that in parts with relative high salinity $(6.8 \mathrm{dS} / \mathrm{m})$. The obtained data showed also that the integration of satellite imagery and GIS has enabled new evaluation possibilities in agricultural areas in relative short time and low costs to put proper soil improvement program.
\end{abstract}

Keywords: Remote Sensing, GIS, Ground water depth, Biomass yield, Soil salinity, Nile Delta

\section{Introduction}

In arid and semi-arid regions, salinity is a serious and chronic problem for agricultural production (Chen et al., 2010). Salinity causes unfavorable environment and hydrological situation for crop production, depending on the degree of salinity at the critical stages of the plant growth, which reduces yield, especially in the dry season (Rasel et al., 2013). Semiz et al. (2012) reported that increasing ECe decreased biomass production of fennel. Salinity also, is a major limiting factor for crop yield in poorly drained soils (Patel et al., 2002). Also, increasing ECe up to $13.4 \mathrm{dS} / \mathrm{m}$ decreased cotton and wheat yields by $29.6 \%$ and $35.4 \%$, respectively (Cullu, 2003). Mitigating this problem requires assessing and measuring soil ECe in a quick, reliable and cost-effective manner (Amezketa, 2007). Assessing soil ECe can be done using apparent electro conductivity (ECa) measured by EM38 and a small amount of soil samples (Lesch et al., 2006), to map the spatial distribution of soil ECe (Wu et al., 2009).Also, Aboelsoud and Abdel-Rahman (2017) reported that EM38 with satellite images can be used to produce salinity maps in a short time and low

"Corresponding author: E-mail:megahedamer3@gmail.com

DOI: 10.21608/ejss.2017.1909.1135

C2018 National Information and Documentation Centre (NIDOC) 
costs. Therefore, measureming ECa is a reliable, rapid means of establishing the spatial variability of soil physicochemical properties associated with variations in crop yield (Corwin et al., 2003).

Water-table depth is an important factor for soil salinity. Plants derive water directly from the shallow groundwater table, cause upward capillary flow of groundwater and bring salts into the root zones, especially with poor water quality (ElNashar, 2013).So, the increase of groundwater ET by crop led to the buildup of salinity (Karimova et al., 2014) depending on groundwater position and soil and crop characteristics (Soppe and Ayars, 2003).However, shallow ground water is considered one of the affective factors of salinity as salinity rising up by capillary action (Mohamed et al., 2011 and 2013).Crop production can suffer as a result of water logging and/or excess soil salinity (Houk et al., 2004). It can be stated in a general way that the water logging problems in arid and semi-arid regions are usually associated with high salinity (Kandil et al., 1995) and there is a close relation between soil ECe and the drainage conditions (Goossens et al., 1993).

The water infiltration of soil is decreased by time in poor structured soils. Therefore, the infiltration rate can be restricted by poor soil management, where the water does not readily enter the soil and moves down or ponds on the surface and evaporates (Haghnazari et al., 2015). Thus, less water is stored in the soil for plant growth, resulting in less plant production. Starting with a dry soil, the infiltration rate is high and as the pores filled with water the suction gradient decreases and by time it approaches zero (Laland Shukla, 2004). Whereas most soils have low permeability, their infiltration capacity tends to decrease greatly due to corruption of soil structure as soils are saturated (Wang et al., 2012). However, soil texture influences the rates at which groundwater can flow from the saturated zone to roots through its influence on hydraulic conductivity (Hillel, 1998) and the infiltration rate was higher in deep water table than in shallow water table (Shermohammadi and Skaggs, 1984).

Watertable depth is an important factor for crop production. Although shallow ground water can represent a highly valuable resource, it may also entail a serious risk when its depth reaches detrimental levels to vegetation (Jobba'gy and Jackson, 2007) due to water logging and root anoxia (Ayars et al., 2006 and Nosetto et al., 2009) or due to soil salinity (Khan and Hanjra,
2008). Also, Brisson et al. (2002) observed that when water table is very shallow, soil water logging limited the growth of wheat roots due to the reduced oxygen in the soil.However, Kahlown et al. (2005) reported that crops tolerant to water logging will be more likely to grow with shallow water table conditions. Thus, the yield in the non-waterlogged area was double as compared to the waterlogged conditions (Kakar, 2000) while the relative yields of the winter wheat and bean in the drained soils were higher by $11.2 \%$ and $24.7 \%$, respectively than improper drained soils (Kale, 2012). On the other hand, corn grain yields in the $80-\mathrm{cm}$ watertable depth were significantly reduced and the maximum grain yields were obtained with a $60-\mathrm{cm}$ depth (Tan et al., 1995), while the lowest yields were obtained with 20-30 cm depth in loamy and silty loamy soils (KalitaandKanwar, 1993). Also, the greatest soybean yields were recorded with water-table depth of 60-cm (Mortazavi et al., 2015), with $70 \mathrm{~cm}$ (Shimada et al., 1997) or with 15-30 cm (Nathanson et al., 1984), while with water table below $15 \mathrm{~cm}$, its yield was $48 \%$ less than that with $60 \mathrm{~cm}$ (Sarwar, 2002). They added that water table oscillating between 1.2 and $2.0 \mathrm{~m}$ deep is optimal to obtain a high yield of corn, sunflower, wheat and sorghum. KahlownandIqbal (1999) also reported that a water table depth of greater than $2.0 \mathrm{~m}$ was more favorable for cotton, 1.0 to $2.0 \mathrm{~m}$ for wheat, and less than $1.0 \mathrm{~m}$ for rice. Moreover, the optimal depth of the water table to obtain maximum yield was found to be $2.0 \mathrm{~m}$ for corn and sunflower, 1.2$1.5 \mathrm{~m}$ for wheat (Kang et al., 2001) and 0.61-0.76 $\mathrm{m}$ for beans (Williamson,1968). Florio et al. (2014) using analyzing MODIS and Landsat images, stated that maize yield with deep water-tables $(>4.0 \mathrm{~m})$ was significantly reduced to be between a quarter and a half of yields with optimum depth (1.5-2.5 m), especially during dry seasons.

The integration of satellite imagery and GIS has enabled new evaluation possibilities in agricultural areas. Despite some criticisms, remote sensing techniques have been shown to be a rapid and useful tool in monitoring and predicting saltrelated crop productivity problems (White, 1997). The use of satellite imagery for monitoring salinity has proved feasible in large areas where salinity is already a serious problem (Metternicht, 2001). Also,remote sensing and GIS are useful tools for estimating the effects of soil salinity on crop production (Cullu, 2003). In addition, if the yield correlates with ECa, maps of ECa will be useful to identify soil properties influencing yield within a field (Corwin et al., 2003).Eric et al. (2004)

Egypt. J. Soil. Sci. 58, No. 1 (2018) 
reported that numerous commercial EC mapping systems are being used in precision agriculture, and many of these maps are being layered in a GIS with yield data to explain yield variability. Finally, Singh et al. (2016) reported that the use of electromagnetic induction along with geospatial modeling provide a better opportunity for understanding spatial distribution of soil properties and crop yields on a landscape level and to map site-specific management zones. The objective of this study, therefore, was to evaluate the impact of water table depths on soil salinity and crop biomass yield in North Nile Delta using remote sensing and GIS.

\section{Materials and Methods}

This study was performed, in about 200 ha at North Nile Delta-Egypt, during 2015/2016 to evaluate the impact of water table depths on soil salinity changes and crop biomass yield using remote sensing and GIS techniques. The area lies between $31^{\circ} 14^{\prime} 0.0^{\prime \prime}$ and $31^{\circ} 11^{\prime} 0.0^{\prime \prime} \mathrm{N}$ and $30^{\circ}$ $58^{\prime} 0.0^{\prime \prime}$ and $31^{\circ} 01^{\prime}$ 0.0" E (Fig.1). The mean annual temperature ranged between $5.7-34.2{ }^{\circ} \mathrm{C}$ and the average annual precipitation was about $150 \mathrm{~mm}$. The area is a new reclaimed clayey soil (EC values varied from 5 to $8 \mathrm{dS} / \mathrm{m}$ ) with low hydraulic conductivity (HC) and infiltration rate (IR). The chemical and physical analysis was carried out using the methods outlined in Black (1965) and Jackson (1967) and the results obtained are shown in Tables 1 and 2.The area is under subsurface drainage system installed at a depth of approximately $2.0 \mathrm{~m}$ with $25 \mathrm{~m}$ laterals spacing. The water table in this area ranged between 0.5 $1.5 \mathrm{~m}$ below the ground surface.

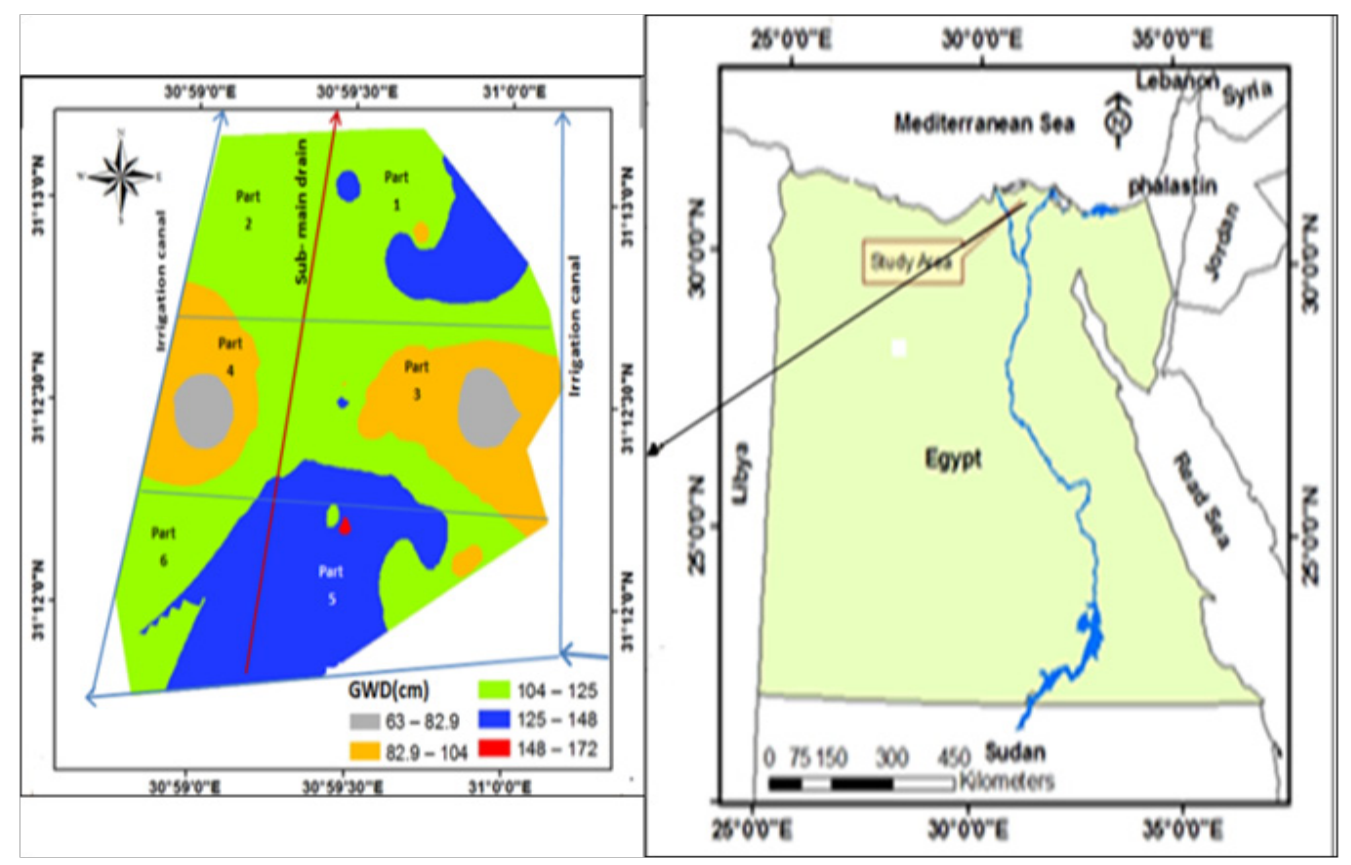

Fig. 1. The studied area

TABLE 1. The average value of the main physical properties of the soil of the studied area.

\begin{tabular}{ccccccccc}
\hline $\begin{array}{c}\text { Depth } \\
(\mathbf{c m})\end{array}$ & $\begin{array}{c}\text { Soil FC } \\
\mathbf{( \% )}\end{array}$ & $\begin{array}{c}\mathbf{I R} \\
\mathbf{c m} / \mathbf{h}\end{array}$ & $\begin{array}{c}\text { HC } \\
\mathbf{m} / \mathbf{d a y}\end{array}$ & $\begin{array}{c}\mathbf{B D}(\mathbf{t o n} / \\
\left.\mathbf{m}^{\mathbf{3}}\right)\end{array}$ & $\begin{array}{c}\text { Sand } \\
\mathbf{\%}\end{array}$ & $\begin{array}{c}\text { Silt } \\
\mathbf{\%}\end{array}$ & $\begin{array}{c}\text { Clay } \\
\mathbf{\%}\end{array}$ & $\begin{array}{c}\text { Soil } \\
\text { texture }\end{array}$ \\
\hline $0-30$ & 41.6 & $0.4-0.8$ & $0.12-0.26$ & 1.30 & 17.9 & 26.6 & 55.5 & Clayey \\
$30-60$ & 43.1 & - & - & 1.33 & 18.2 & 25.8 & 56.0 & Clayey \\
$60-90$ & 43.5 & - & - & 1.38 & 18.2 & 24.2 & 57.6 & Clayey \\
\hline
\end{tabular}


TABLE 2. The average value of the main chemical properties of the soil of the studied area

\begin{tabular}{|c|c|c|c|c|c|c|c|c|c|c|c|c|}
\hline \multirow{2}{*}{$\begin{array}{l}\text { Depth } \\
(\mathrm{cm})\end{array}$} & \multirow{2}{*}{$\begin{array}{c}\text { ECe } \\
(d S / m)\end{array}$} & \multicolumn{4}{|c|}{ Soluble cations (meq/l) } & \multicolumn{4}{|c|}{ Soluble anions(meq/l) } & \multirow{2}{*}{ SAR } & \multirow{2}{*}{$\begin{array}{c}\mathrm{Mg}^{2+} / \\
\mathrm{Ca}^{2+}\end{array}$} & \multirow{2}{*}{ pH } \\
\hline & & $\mathrm{Na}^{+}$ & $\mathbf{K}^{+}$ & $\mathrm{Ca}^{++}$ & $\mathbf{M g}^{++}$ & $\mathrm{CO}_{r}^{=}$ & $\mathrm{HCO}_{r}^{-}$ & $\mathrm{Cl}^{-}$ & $\mathrm{SO}_{4}=$ & & & \\
\hline $0-30$ & 5.58 & 37.5 & 0.6 & 11.8 & 13.5 & 0.0 & 5.0 & 25.2 & 33.1 & 10.5 & 1.1 & 8.1 \\
\hline $30-60$ & 6.61 & 42.5 & 0.5 & 13.8 & 16.5 & 0.0 & 5.0 & 30.2 & 38.0 & 10.9 & 1.2 & 8.1 \\
\hline $60-90$ & 8.12 & 53.1 & 0.6 & 16.9 & 19.6 & 0.0 & 5.0 & 37.0 & 48.2 & 12.4 & 1.2 & 8.2 \\
\hline
\end{tabular}

\section{Groundwater position}

The groundwater depth (GWD) was monitored in 18 observation wells in the period from July 2015 to June 2016, manually in 10 observation wells using a float with electric sounder attached to a scaled steel tape (Fig. 2-a). While electronic pressure sensors were installed in 8 observation wells for automated recording of groundwater levels at one hour increments (Fig. 2-b). These instruments measure the weight of the water column plus the atmosphere pressure situated above the sensor (Fig. 2-c), and consequently the depth from soil surface to groundwater level can be calculated. The GWD after $24 \mathrm{hr}, 48 \mathrm{hr}$ and at its maximum value after irrigation were recorded. Also, the downward movement rate (DDR) of water table $(\mathrm{cm} /$ day) and the duration time (DT), which is the time for water table to reach the deepest depth after irrigation were calculated.

\section{Soil salinity}

The distribution of soil salinity was characterized by soil sampling and electromagnetic induction using EM38 (Fig. 2-d). Advantage of the apparent soil salinity (ECa) based soil survey is the high number of measurements per area unit to create maps with a very high spatial resolution, as needed for precision farming. The EM38 was operated in both horizontal and vertical modes to characterize the apparent soil salinity (ECa) distribution in 500 locations to cover the area of study. The EM readings were performed at relative high soil moisture content to minimize the effect of soil moisture variations. These measurements were carried out a few days after heavy rain at middle morning period to avoid the big difference in soil moisture and temperature in surface soil layer.The ECa data were calibrated to ECe using soil samples taken from 30 randomly selected sites in the depths of 0-30, 30-60 and 60-90 cm at the time of EM survey, and ECe was determined in soil paste extract. The ECe values predicted from ECa data were tracked with GPS that enabled them to be plotted on a map that corresponds to the other maps being used (water table and biomass yield). Salinity map was produced using Ordinary Kriging and the Geostatistical analyst in ArcGIS 10.1 according to ESRI (2012).

\section{Crop classification}

Initial unsupervised classification was applied, which is an automated cluster analysis technique that uses a minimum spectral distance cluster algorithm to assign a pixel to a cluster of pixels with a similar attribute. The coordinates of the four corners for each selected field were recorded using the GPS.Supervised classification was used for accurate and precise clustering of pixels into land use/land cover classes (Campbell, 1996). Land use and crop classification were extracted and identified from the satellite images during one particular day. Therefore, Landsat ETM+ imagery, acquired in July 17th, 2015, and March 15th 2016 with $30 \mathrm{~m}$ ground resolution was used to record crop classification of both growing seasons. These selected days were suitable for spotting rice, cotton, maize and seed melon in summer season and wheat, clover and sugar beet in winter season.

\section{Calculation of biomass production}

The Normalize Difference Vegetation Index (NDVI) is an effective indicator of the surface coverage condition for vegetation and also to show the stage of growth of the crop canopy. The NDVI is calculated by the following equation:

$$
\mathrm{NDVI}=(\mathrm{NIR}-\mathrm{RED}) /(\mathrm{NIR}+\mathrm{RED})
$$

where, NIR; near infrared band and RED; red band (band 4 and 3 in ETM data, respectively).

The NDVI equation produces values in the range from -1 to +1 , where vegetated areas typically have values greater than 0.2 and less values indicate non/vegetated surface features such as water, barren or clouds. NDVI values vary according to crop age, planting density and chlorophyll activity. The relation between NDVI value and the actual crop yields were used to calculate the biomass production for different summer and winter crops using satellite images according to Maynard et al. (2006). 

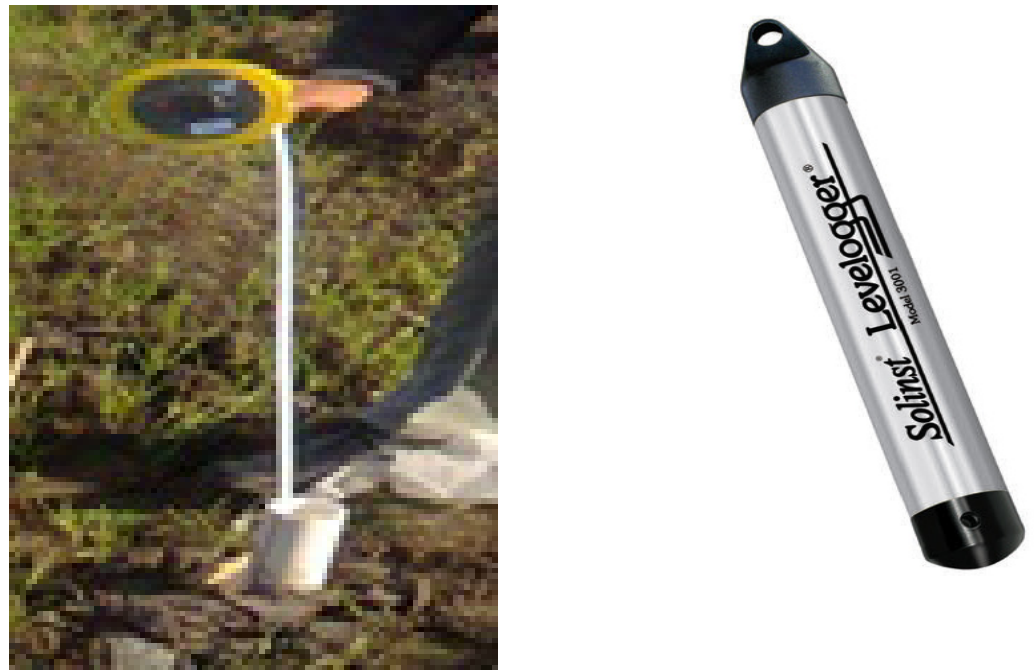

a
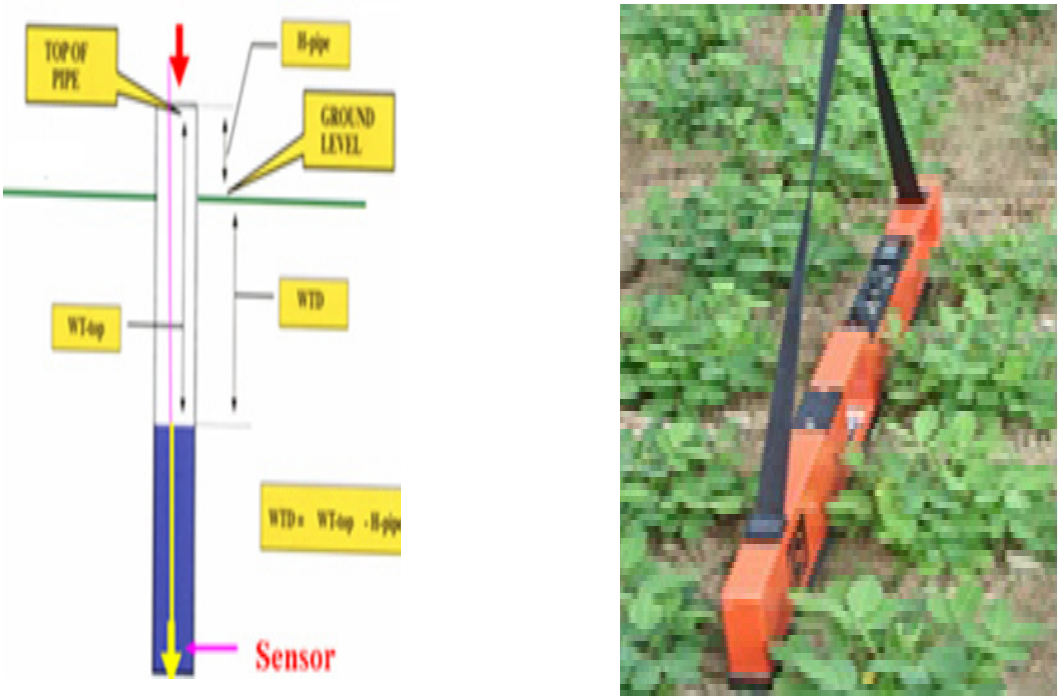

$\mathrm{c}$

Fig. 2. Manual float with electronic sounder (a), automated sensor (b), schematic of observation well (c) and $\mathbf{E M}_{38}$ to measure apparent soil salinity in the field (d)

\section{Results and Discussions}

Water table status in the study area

The drainage data for the area of study are given in Table 3 and Fig. 3,4. The values of water table in the area are mainly affected by drainage system status and they can be taken to evaluate the performance of the drainage system. The depth of ground water $(\mathrm{GW})$ was obviously shallow on the subsurface collector in Parts 3 since it recorded the lowest depths after $24 \mathrm{hr}, 48 \mathrm{hr}$ and at the end of the duration period from irrigation $(31.0,42.2$ and $80.9 \mathrm{~cm}$, respectively). While GW was slightly deeper on the collector serves Part 4 (35.3, 45.8 and $96.9 \mathrm{~cm}$, respectively). The deepest GW after
$24 \mathrm{hr}, 48 \mathrm{hr}$ and at the end of the duration period were achieved in Part 1 (58.7, 76.9 and $126.0 \mathrm{~cm}$, respectively) with an average of $87.2 \mathrm{~cm}$ followed by Part $6(36.4,61.4$ and $124.9 \mathrm{~cm}$, respectively) with an average of $74.2 \mathrm{~cm}$.

The data revealed that the drawdown rate (DDR) of water table was decreased rapidly by the time, where its values through the $1 \mathrm{st} 24 \mathrm{hr}$ after irrigation ranged between 18.5 and $45.1 \mathrm{~cm} /$ day, then decreased to $14.6-31.2 \mathrm{~cm} /$ day through the $1^{\text {st }} 48 \mathrm{hr}$ after irrigation, while the average values during the drawdown period between the two irrigations were decreased to $6.2-10.1 \mathrm{~cm} /$ day. This behavior may be attributed to the poor 
soil structured since the water infiltration was decreased rapidly by the time and influenced the entry of water to the soil asobserved by Haghnazarietal. (2015). This may be also due to poor drainage system in the area, in addition to improper soil physical properties as a result of increasing $\mathrm{Mg}: \mathrm{Ca}$ ratio in soilis over the unity which causes a reduction in infiltration rate.

The duration time (DT) is the time for water table to reach the deepest level after irrigation. Therefore, not only water table depth is important for sustainable agriculture, but also how long it reaches the deepest level. This means that the deep water table with long duration time may have a negative effect on plant and soil more than the shallow water table with short duration time. The duration time is inversely proportional to the drawdown rate of water table and their values are related mainly to the efficiency of the subsurface drainage system and soil properties. Consequently, the relative long DT (13.1days) with relative low DDR through the $1^{\text {st }} 24,48 \mathrm{hr}$ or through the DT $(18.5,15.1$ or $6.2 \mathrm{~cm} /$ day ,respectively) are recorded with the shallowest $\mathrm{GW}(80.9 \mathrm{~cm})$ in Part3.Otherwise, the shortest DT (9.7 days) with quick DDR through the 1 st $24,48 \mathrm{hr}$ or through the DT $(45.1,31.2$ or $10.1 \mathrm{~cm} /$ day, respectively) are recorded with the deepest GW $(126.0 \mathrm{~cm})$ in Part1.

Finally, there is an obvious relation between the status of drainage system and water table level. So, more efficient the drainage systemis, the deeper is the water table as observed in Parts 1 and 6. Consequently, Part 3 suffers from shallow water table due to poor performance of the drainage system.

TABLE 3. Water table, soil salinity and biomass yield in the area of study(2015/2016)

\begin{tabular}{|c|c|c|c|c|c|c|c|c|c|c|c|}
\hline \multirow[b]{2}{*}{ Part } & \multicolumn{3}{|c|}{ GWD (cm) } & \multirow[b]{2}{*}{$\begin{array}{c}\text { DT } \\
\text { (day) }\end{array}$} & \multicolumn{3}{|c|}{ DDR (cm/day) } & \multirow{2}{*}{$\begin{array}{c}\text { Soil } \\
\text { salinity } \\
\text { (dS/m }\end{array}$} & \multicolumn{3}{|c|}{ Biomass Yield (t/ha) } \\
\hline & $\begin{array}{c}\text { after } \\
24 \mathrm{~h}\end{array}$ & $\begin{array}{c}\text { after } \\
48 \mathrm{~h}\end{array}$ & Max. & & $\begin{array}{c}\text { during } \\
24 \mathrm{~h}\end{array}$ & $\begin{array}{c}\text { during } \\
48 \mathrm{~h}\end{array}$ & $\begin{array}{c}\text { during } \\
\text { DT }\end{array}$ & & $\begin{array}{c}\text { Winter } \\
\text { crops }\end{array}$ & $\begin{array}{c}\text { Summer } \\
\text { crops }\end{array}$ & Mean \\
\hline Part 1 & -58.7 & -76.9 & -126 & 9.7 & 45.1 & 31.2 & 10.1 & 6.01 & 52.7 & 19.7 & 36.2 \\
\hline Part 2 & -28.6 & -45.7 & -104 & 14.7 & 27.1 & 22.8 & 7.1 & 5.68 & 51.0 & 20.6 & 35.8 \\
\hline Part 3 & -31 & -42.2 & -80.9 & 13.1 & 18.5 & 15.1 & 6.2 & 6.77 & 45.5 & 18.6 & 32.0 \\
\hline Part 4 & -35.3 & -45.8 & -96.9 & 13.7 & 18.7 & 14.6 & 6.9 & 4.93 & 47.4 & 21.0 & 34.2 \\
\hline Part 5 & -27.9 & -50.3 & -102.6 & 11.2 & 22.9 & 22 & 8.1 & 5.27 & 46.0 & 19.4 & 32.7 \\
\hline Part 6 & -36.4 & -61.4 & -124.9 & 13.0 & 32.1 & 26.9 & 8.9 & 4.64 & 48.2 & 20.7 & 34.4 \\
\hline Mean & -36.3 & -53.7 & -106.7 & 12.6 & 27.4 & 22.1 & 7.9 & 5.55 & 48.5 & 20.0 & 34.2 \\
\hline
\end{tabular}

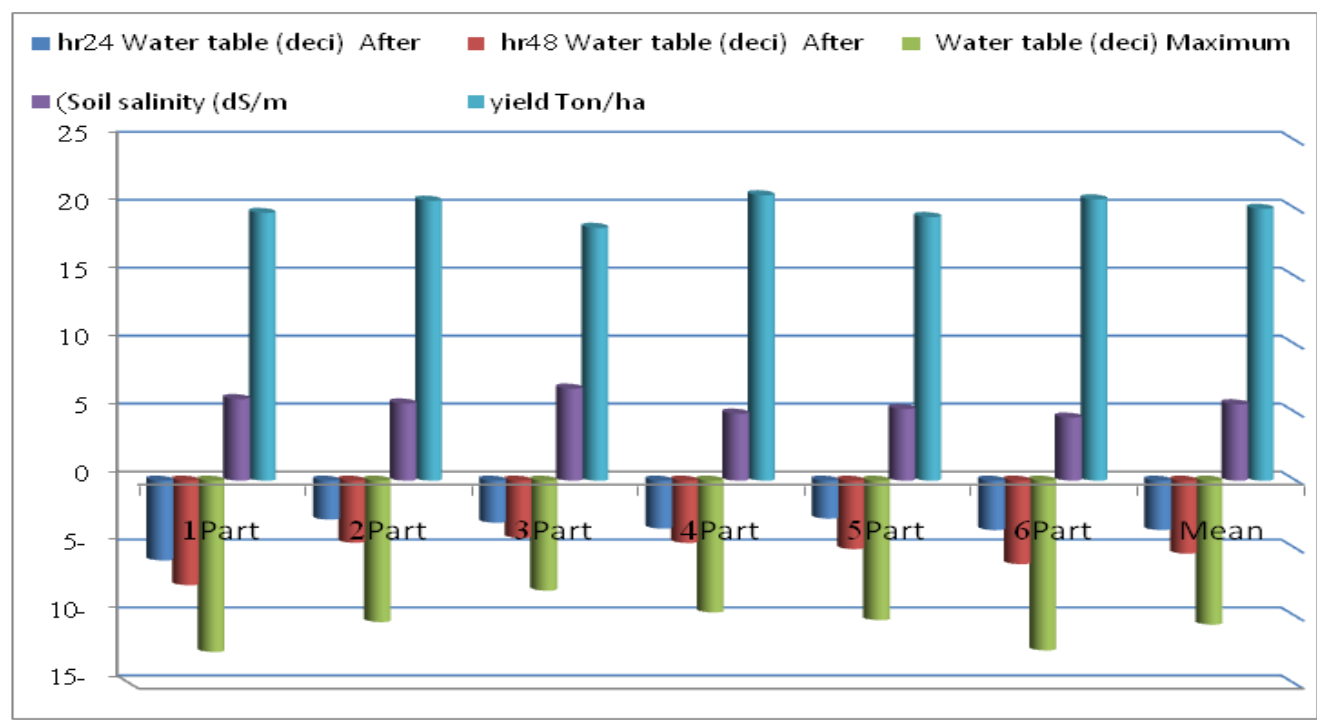

Fig. 3. Water table information in the area of study

Egypt. J. Soil. Sci. 58, No. 1 (2018) 


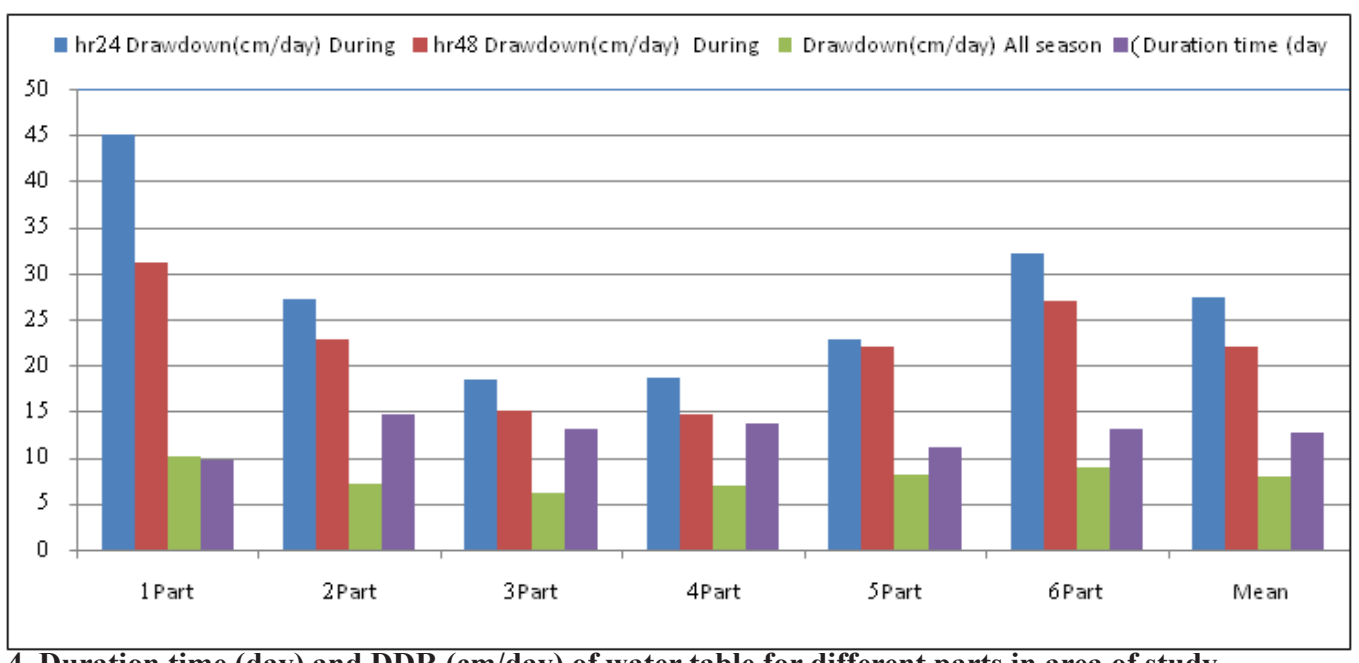

Fig. 4. Duration time (day) and DDR (cm/day) of water table for different parts in area of study

Soil salinity as affected by ground water depth (GWD)

The "salt balance" is a concept that is used to quantify the salt management status within an agricultural area. This will ensure no accumulation of salt in the soil profile and should sustain the production system. The proper management of salts in the crop root zone is a must to limit the accumulation to levels that are injurious to crop production. Salt in the root zone should have to be moved out of the root zone down into the soil profile or into the groundwater. This purpose is achieved through salt disposal into efficient drainage system or planting more salt tolerant crops as the soil becomes more saline. Table 3 and Fig. $3 \& 5$ showed a negative but insignificant correlation between GWD and soil salinity $(\mathrm{R} 2=0.576$ and $\mathrm{r}=-0.483, \mathrm{P}<0.05)$. The coefficients of determination (R2) can be used to explain the variability in soil salinity with different GWD. So, R2 value in Fig 5 indicated that about $60 \%$ of soil ECe value is determined by GWD. Therefore, there are in somewhat relations between the ground water depth and soil salinity, or the deeper is the ground water, the lower is the ECe value. Part 3 which suffers from shallow water table $(80.9 \mathrm{~cm})$ due to poor performance drainage system and its soils, in sequence, had salinity levels higher than that in other Parts $(6.8 \mathrm{dS} / \mathrm{m})$. On the other hand, the lowest salinity level was found in Part $6(4.6 \mathrm{dS} / \mathrm{m})$ which has relatively deep ground water $(124.9 \mathrm{~cm})$. These results are consistent with those obtained by Villa-Castorena et al. (2003) who observed that shallow water tables with insufficient leaching and lack drainage management are the main reasons for soil salinization. The illogical trend was observed in Part 1,where its soils have relatively high salinity level $(6.0 \mathrm{dS} / \mathrm{m})$ with the deepest ground water $(126 \mathrm{~cm})$ and the shortest duration time $(9.7$ days) comparing to other parts. This behaviour can be related to that this part may be suffering from shortage of fresh water, so the farmers have to use drainage water for irrigation and/or add low volume of irrigation water causing accumulation of salts in soil.Also,some farmers have to add some chloride salts to cause slight increase in soil salinity and consequently friability of soilin surface layer especially with sugarbeet.This behavior agrees with Horneck et al. (2007) who suggested that high EC in irrigation water and soil maintains soil structure and increases water infiltration.

Biomass production as affected by GWD and soil salinity

According to the crop classification, the dominant crop in summer season was rice followed by maize, cotton and seedmelon, while in winter season; the dominant crop was wheat followed by clover and sugarbeetas shown in Fig 6. Crop biomass yield is affected mainly by soil salinity and soil moisture stress related to irrigation and drainage managements, crop varieties and farmers skillfulness.Also, EC-yield relationships may invert from year to year, depending on rainfall (Jaynes et al., 1995). Since the GWD and soil salinity are important factors affecting the biomass yield, its value can be predicted from the following relation:

Biomass yield $(\mathrm{t} / \mathrm{ha})=24.8175200968+0.273$ 89266745(GWD)-0.920332671(SS) $(\mathrm{R} 2=0.64)$

Where, GWD, ground water depth (m) and SS, soil salinity $(\mathrm{dS} / \mathrm{m})$.

\section{Relationship between biomass yield and GWD}

The relationship between GWD and biomass yield is more complex, where; it is rarely to be linear correlation. The mean value of biomass yield of summer and winter crops differs positively with GWD, but the relationship is relatively weak according to the resulting value of R2(0.554). Also, aweakpositive correlation was observed between biomass yield and GWD 


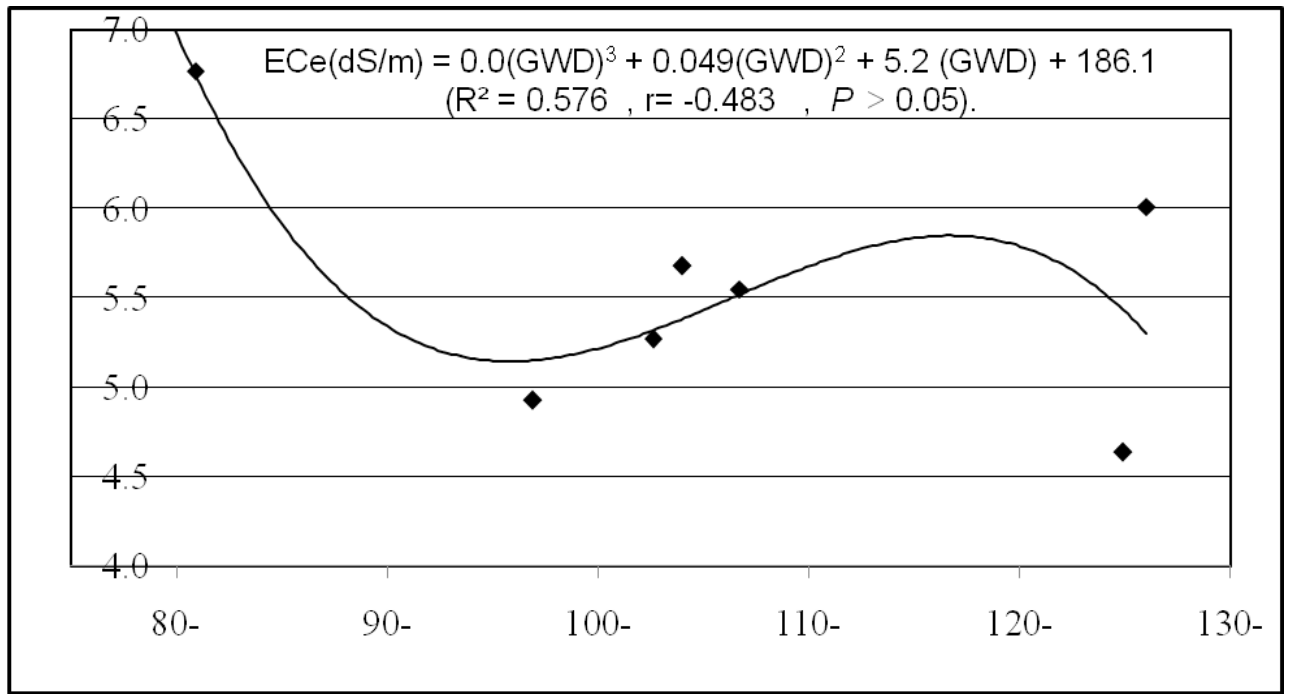

Fig. 5. Soil salinity (dS/m) as affected by GWD (cm)
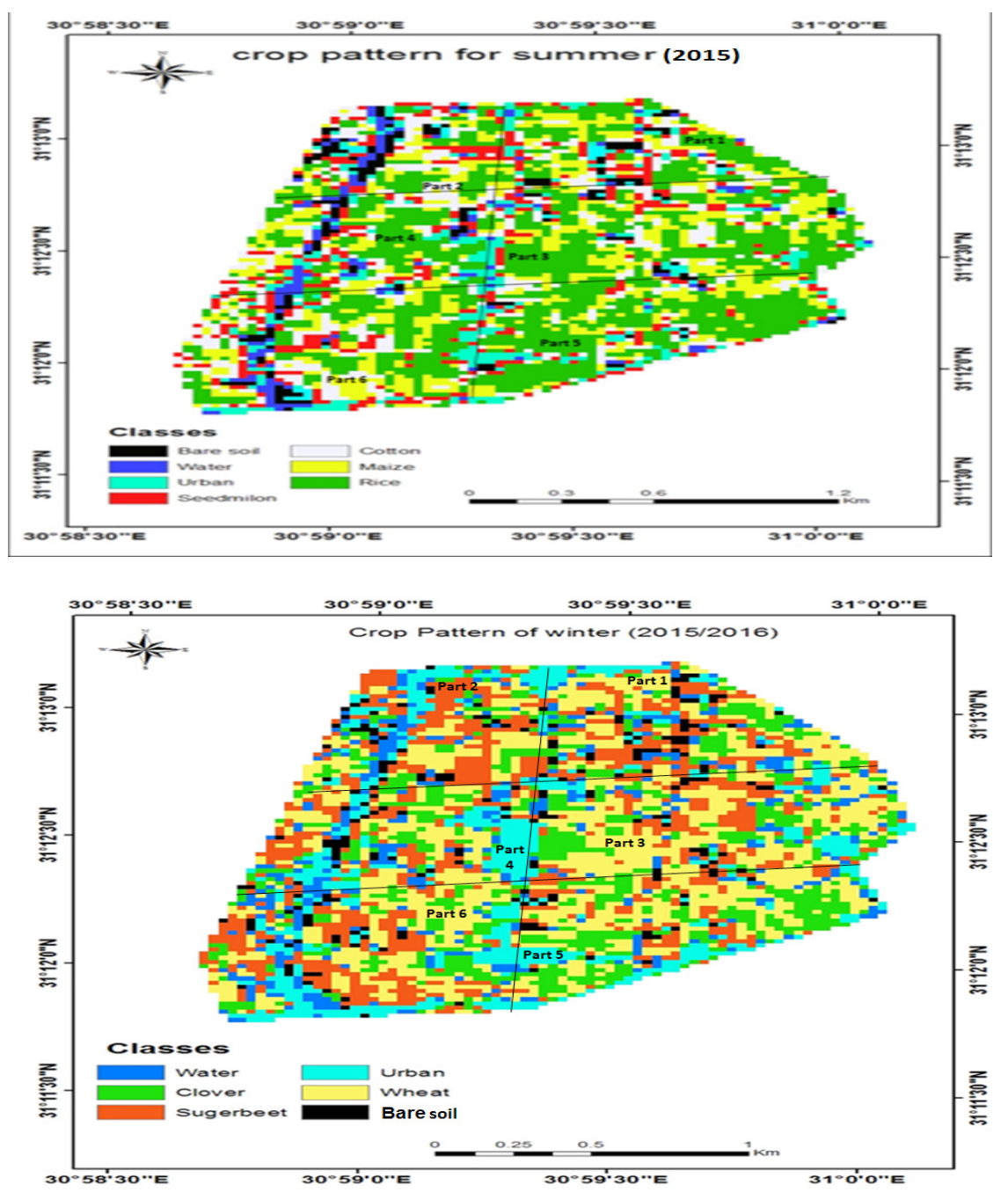

Fig. 6. Crop patternof the studied area for summerand winter seasons

Egypt. J. Soil. Sci. 58, No. 1 (2018) 
$(\mathrm{r}=0.707, \mathrm{P}<0.05)$, as shown in Table 3 and Fig. 7. In addition, coefficients of determination indicated that only $55 \%$ of the biomass yield variability may be related to the GWD values. The obtained trend shows that the biomass yield of crops is increased with increasing GWD up to $126 \mathrm{~cm}$. The maximum biomass yield (36.2 t/ha) was achieved when GWD was approximately $126 \mathrm{~cm}$ in Part 1 while the lowest yield (32 ton/ ha) was observed with about $81 \mathrm{~cm}$ GWD in Part 3. This trend may be related to the aeration and moisture status in soil root zone which depend on GWD. These results are consistent with Pelletier etal. (2015) who reported that the hypoxic stress with shallow ground water could be more damaging than water stress since for each GWD step of $10 \mathrm{~cm}$, the yield increased by $15 \%$ between 25 and $60 \mathrm{~cm}$ due to improving soil aeration and decreased by $8 \%$ between 60 and $120 \mathrm{~cm}$ due to increasing soil moisture stress. Also, oxygen supplies to a crops root, nutrient uptake, crop growth, and yield are reduced as a result of a shallow water table (Wesseling, 1974).In general, when a shallow water table exists, the yields of most crops can be related to their root lengths. Therefore, the optimum water table depth, at which aeration, moisture, and nutrients are available, can maximize the yields of most crops. While, with water table above this threshold depth, crop yields begin to decline (Evans and Fausey, 1999).

The relationship between doil ECe and biomass yield

Table 3 and Fig. 3 show data from the studied area exhibiting soil EC-biomass yield relationship. A negative significant correlation was observed between root zone electrical conductivity and biomass yield especially in summer season $(\mathrm{r}=-0.80, \mathrm{P}>0.05)$. On the other hand, coefficients of determination, R2 (0.69) indicated that more than $67 \%$ of crop biomass variability is determined by ECe as shown in Fig 8.These data suggest that the yield potential with low ECe in Parts 4 and 6 (4.64-4.93 dS/m) is about $10 \%$ higher than that with relatively high soil salinity in Part $3(6.77 \mathrm{dS} / \mathrm{m})$. These results are consistent with those observed by Ayers and Westcot (1985) who reported that soil salinity problem exists when the buildup of salts in a crops root zone is significant enough to decrease crop yield.Also, Maas and Hoffman (1977) concluded that crops are generally unaffected by salinity up to a threshold at which the yield begin to decrease linearly as soil salinity levels increase.
On the other hand, the relationship between soil ECe and yield has been reported and quantified by Fleming, et al. (1998).Also, soil is the primary growth medium for crops, so it is not surprising that maps of soil physical properties and yield maps show visible correlation. Therefore, soil ECe can serve as a proxy for soil physical properties such as organic matter (Jaynes et al., 1994). These properties have a significant effect on water and nutrient-holding capacity, which are major drivers of yield (Jaynes, 1995). They added that ECe-yield relationships must be taken in consideration since it may be inverted, depending on the annual rainfall.

\section{TheIntegration of Satellite Imagery and Geographic Information System}

This has enabled new evaluation possibilities in agricultural areas in relative short time and low costs. The correlation analysis is an important first step in investigating the causes of yield variability. The visual similarities of the maps and the statistical correlation of the data indicate that the patterns are not random as shown in Fig (9). Different trends begin to be observed in the field and illustrated in maps using remote sensing and GIS techniques, while the correlation analysis shows how bad the impacts of both soil salinity and GWD on the biomass production of the plant cover in the investigatedarea. For example, shallow GWDcauses relative high soil salinity level and both causelowcropbiomass yield as shown in Part 3.In the contrast, deep GWD causes relative low salinity level in soil and both cause highercrop biomass yield as observed in Parts 1, 5 and 6 (Fig 9). This view is in somewhatagreed withWu, et al (2008)who reported that the overall accuracy of remote sensing in detectingsoil salinitywas $90.2 \%$, and in detecting cropped area, $98 \%$, consequently the remote sensing is a useful tool to detect soil salinity and has potential in evaluating and improving land and water management practices.

\section{Conclusion}

The GWD in the investigated area is mainly affected by drainage system status and it can be taken to evaluate the performance of the drainage system. So, more efficient the drainage system, the deeper is the GW. The GWD in the investigated area ranged between 50 and $150 \mathrm{~cm}$ based on the performance status of the tile drainage collectors. The DDR of GW was decreased rapidly by the time, due to poor structured soil. DDR recorded $6.2-10.1 \mathrm{~cm} /$ day through DT which is the time 


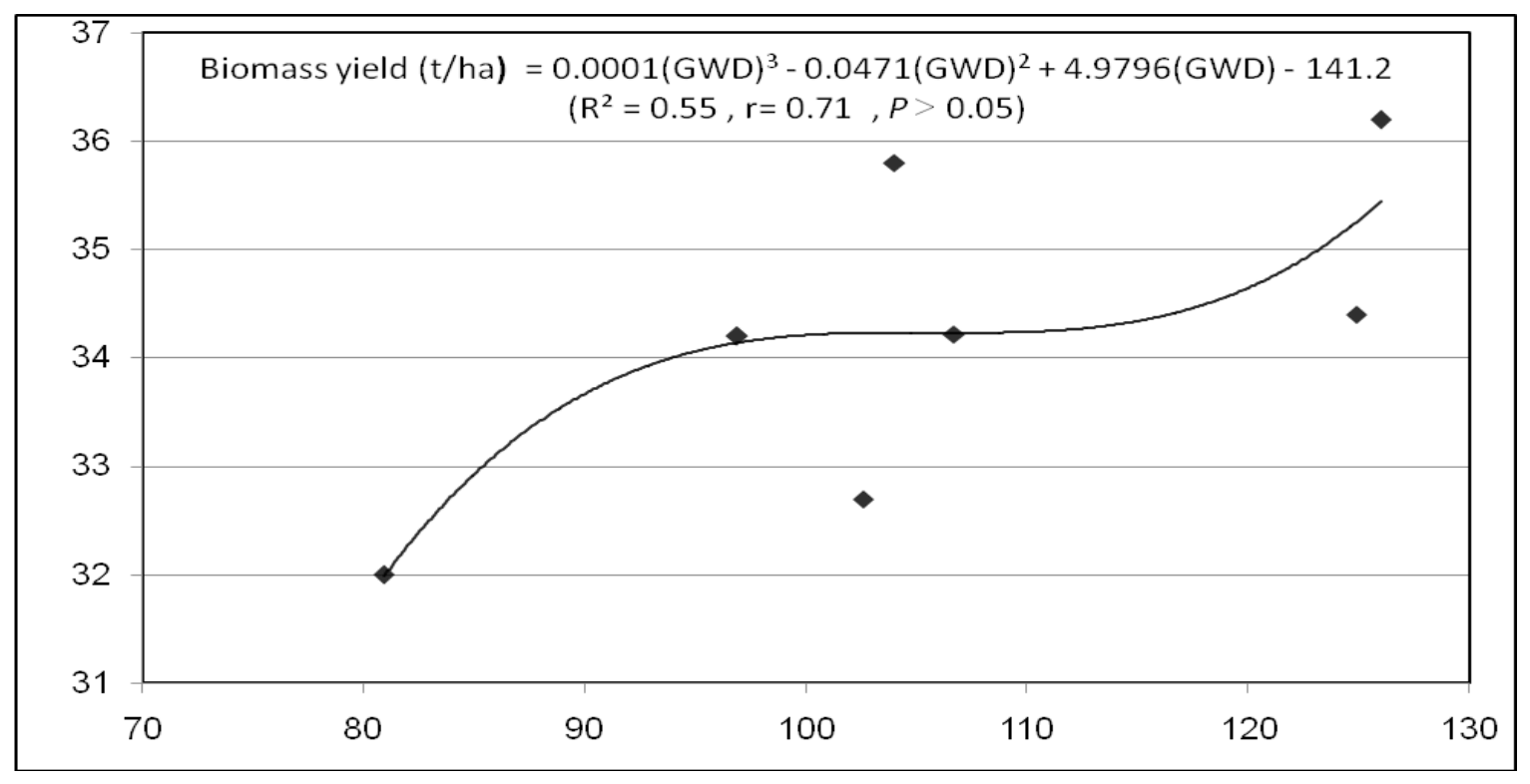

Fig.7. Mean biomass yield of both seasons (t/ha) as affected by GWD (cm)

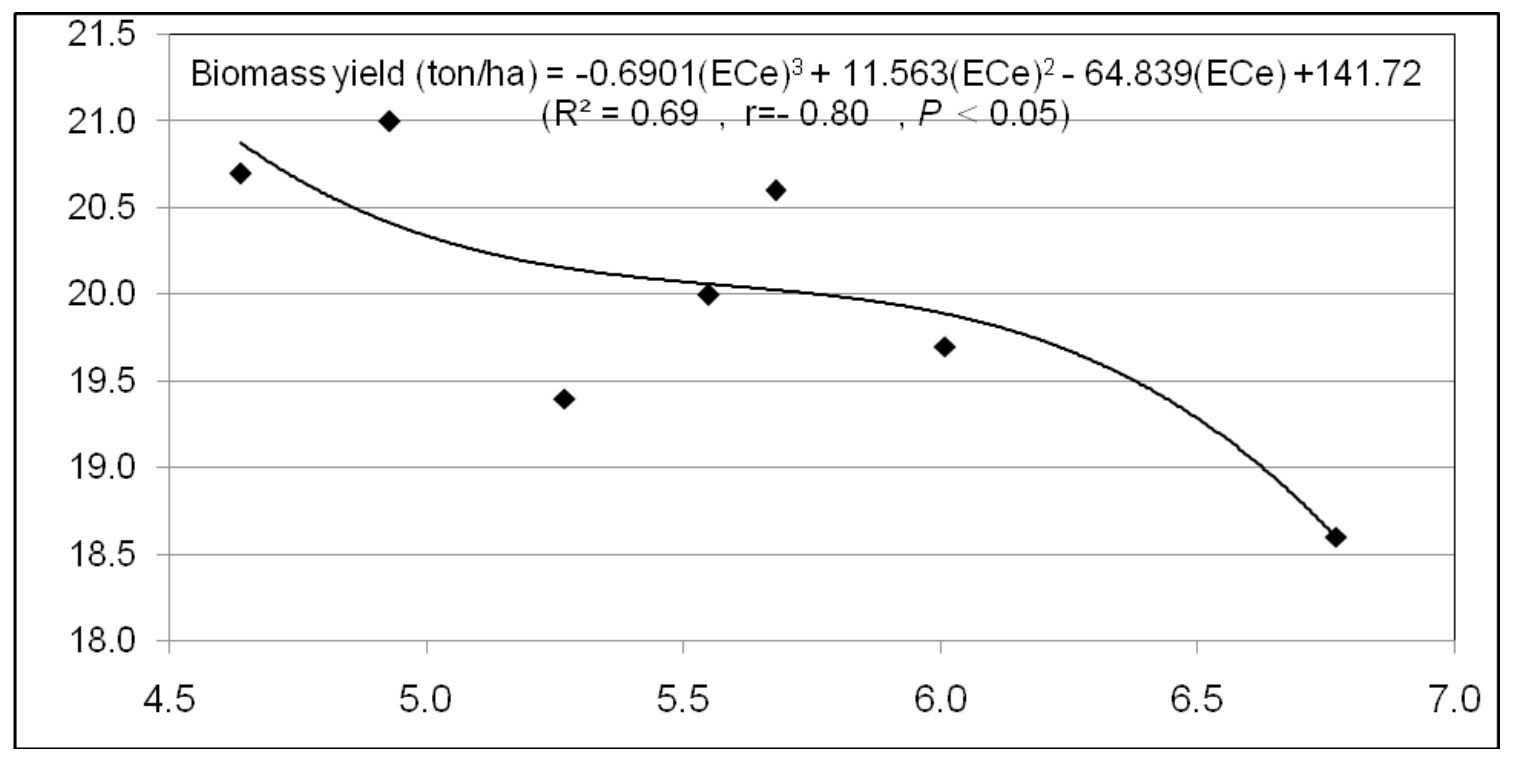

Fig.8. Biomass yield (t/ha) of summer season as affected bysoil ECe (dS/m) 

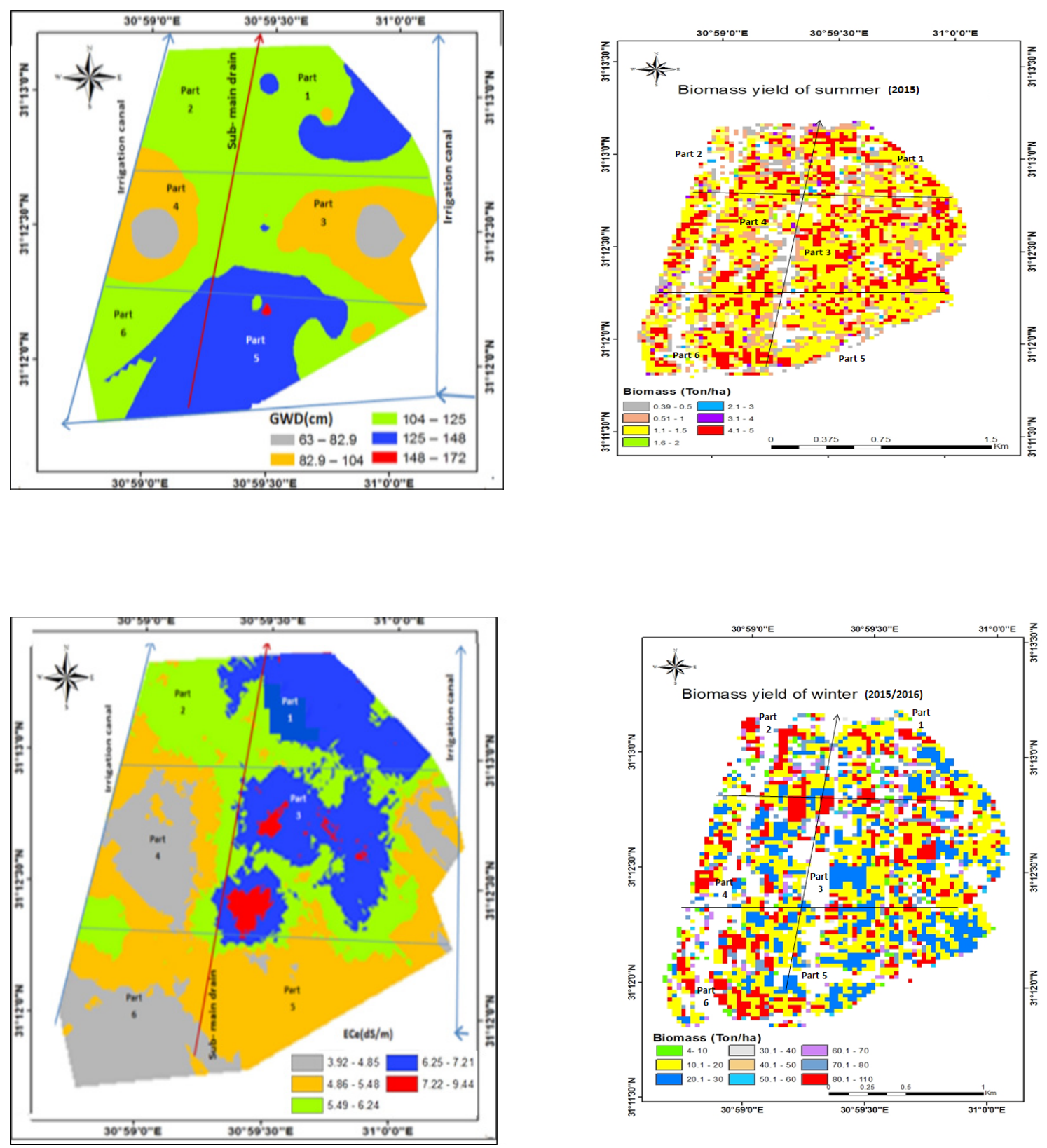

Fig. 9. GW distribution (a), EM38 survey of soil salinity (dS/m) in root zone (b), and biomass contour maps of summer (c) and winter (d) seasons in the investigated area (ton/ha). 
for water table to reach the deepest level after irrigation. The DT is inversely proportional to the DDR of GW and their values are related mainly to the efficiency of the subsurface drainage system and soil properties. Consequently, the shallowest GW was recorded with the relative long DT with relative slow DDR and vice versa.

A negative significant correlation was found between the GWD and soil salinity. Also, a positive weak correlation was observed between biomass yield and GWD, whereas its correlation with the root zone electrical conductivity was significant and negative. The yield potential in parts with low EC soils was about $10 \%$ higher than that in parts with relatively high salinity.

The integration of satellite imagery and GIS has enabled new evaluation possibilities in agricultural areas in relative short time and low costs according also to Eldiery et al. (2005). They reported that the availability and ease of acquiring satellite imagery to estimate soil salinity was very attractive compared to the labor, time, and money invested in field work devoted to collecting soil salinity data.

The slow drawdown rate of the excess water through soil profile after irrigation indicated that the tile drainage system in the area is not efficient and/or the soil is compacted due to unfavorable chemical and physical properties. So, the new facilities can be used to evaluate the productivity of soil in wide area as affected by ground water depth and soil properties in short time and low costs. This is necessary to put proper soil improvement program, i.e. a-sub-soiling, bapplication of some soil amendments such as gypsum, sulfur or compost and c- maintenance or rehabilitation of the tile and open drainage systems in the investigated area.

\section{Acknowledgments}

This research has been supported by the sensors used for recording the ground water depths from ICARA office in Giza-Egypt through the "Management of Water and Salinity in the Nile Delta Project", while EM38 was provided by the Canadian AGRA Office through On-Farm Soil and Water Management Project. The authors acknowledge both of them.

\section{References}

Aboelsoud, H. M. and Abdel-Rahman, M. A. E. (2017) Rapid Field Technique for Soil Salinity

Egypt. J. Soil. Sci. 58, No. 1 (2018)
Appraisal inNorth Nile Delta Using EM38 through SomeEmpirical Relations.International Journal of Plant and Soil Science, 14 (5).

Ame'zketa, E. (2007) Soil salinity assessment using directed soil sampling from a geophysical survey with electromagnetic technology: a case study. Spanish Journal of Agricultural Research, 5 (1), 91-101. Available online at www.inia.es/sjar.

Ayars, J.E., Christen, E.W., Soppe, R.W., and Mayers, W.S., (2006) The resource potential of in-situ shallow ground water use in irrigated agriculture: a review. Irrig. Sci. 24 (3), 47-160.

Ayers, R.S., and Westcot, D.W. (1985)Water Quality for Agriculture. FAO Irrigation and Drainage Paper 29 Rev.1.

Black, C.A. (1965) Methods of Soil Analysis. Amer. Soc.Agro. Inc., Madison, Wisconsin, U.S.A.

Brisson, N., Rebisre, B., Zimmer, D. and Renault, P. (2002) Response of the root system of a winter wheat crop to waterlogging. Plant Soil, 243, 43-55.

Campbell, C.A., McConkey, B.G., Zenter, R.P., Selles, F. and Curtin, D. (1996) Long-term effects of tillage and crop rotations on soil organic $\mathrm{C}$ and total $\mathrm{N}$ in a clay soil in southwestern Saskatchewan. Canadian Journal of Soil Science 76(3): 395-401.

Chen,W., Hou, Z., Wu, L. , Liang,Y. and Wei ,C. (2010) Evaluating salinity distribution in soil irrigated with saline water in arid regions of northwest China, Agricultural Water Management. 97 (12), 2001-2008.

Corwin, D.L., Lesch, S.M., Shouse, P.J., Soppe, R., and Ayars, J.E., (2003) Identifying soil properties that influence cotton yield using soil sampling directed by apparent soil electrical conductivity. Agron. J. 95 (2), 352-364.

Cullu, M. A. (2003) Estimation of the Effect of Soil Salinity on Crop Yield Using Remote Sensing and Geographic Information System. Turk. J. Agric. For. 27, 23-28.

Eldiery, A., Garcia, L.A. and Reich, R.M.(2005) Estimating soil salinity from remote sensing data in corn fields, Hydrology Days.

El-Nashar, Walaa Y. (2013) The Combined Effect of Water-logging and Salinity on Crops Yield. Journal of Agriculture and Veterinary Science (IOSR-JAVS) e-ISSN: 2319-2380, p-ISSN: 2319-2372. Volume 6, Issue 4, 40-49.

Eric, E. Houk, Frasier, M. andSchuck, E. (2004) The regional effects of waterlogging and soil 
salinization on a rural county in the Arkansas River Basin of Colorado.Selected paper presented for presentation at the Western Agricultural Economics Association, Annual Meeting, and Honolulu, HI. June 30. July 2, 2004.

ESRI (2012) Arc GIS Geostatistical Analysis.Tutorial (ArcGIS ${ }^{\circledR} 10.1$ ).Printed in the USA.

Evans, R. O., and Fausey, N. R. (1999) Effects of Inadequate Drainage on Crop Growth and Yield.. Agricultural Drainage, Agronomy Monograph no. 38: 13-54. Madison, WI: ASA.

Fleming, K.L., Westphall, D.G., Wiens, D.W., Rothe, L.E., Cipra, J.E. andHeerman, D.F. (1998) Proceedings of 4th International Conference on Precision Agriculture, 335-343.

Florio, E.L., Mercau, J.L., Jobbágy, E.G. and Nosetto, M.D.(2014) Interactive effects of water-table depth, rainfall variation, and sowing date on maize production in the Western Pampas. Agricultural Water Management, 146, 75-83.

Goossens, R., De Dapper, M., Gad, A. and Ghabour, T. (1993) A model for monitoring and prediction of soil salinity and waterlogging in the Ismaillia area (Egypt), based on remote sensing and GIS. Proceedings of the International Symposium on 'Operationalization of Remote Sensing, 6, 97-107.

Haghnazari, F., Shahgholi, H. andFeizi, M. (2015) Factors affecting the infiltration of agricultural soils: review. International J. of Agronomy and Agricultural Research (IJAAR), ISSN: 2223-7054 (Print) 2225-3610 (Online), 6(5):21-35.

Hillel, D. (1998) Environmental Soil Physics. Academic Press, San Diego.

Horneck, D.A., Ellsworth, J.W. Hopkins, B.G. Sullivan, D.M. and Stevens, R.G. (2007) Managing of salt-affected soils for crop production.PNW601-E. Nov., 2007.

Houk, E.E., Frasier, M. and Schuck, E. (2004) The regional effects of waterlogging and soil salinization on rural county in the Arkansas River Basin of Colorado.Annual Meeting, Honolulu, HI. June 30. July 2, 2004.

Jackson, M.L. (1967) Soil Chemical Analysis Advanced Course.Puble.By the author, Dept. of Soils, Univ. of Wise.Madison 6, Wishensin, USA.

Jaynes, D.B., Colvin, T.S., Ambuel, J. (1995) Yield Mapping by Electromagnetic Induction. Proceedings of the 2nd International Conference on Site-Specific Management for Agricultural Systems,383-394.
Jaynes, D.B., Novak, J.M., Moorman, T.B., Cambardella, C.A. (1994) Estimating Herbicide Partition Coefficients from Electromagnetic Induction Measurements. J. Environmental Quality, 24, 36-41.

Jobba' gy, E.G., Jackson, R.B. (2007) Groundwater and soil chemical changes under phreatophytic tree plantations. J. Geophys. Res. 112, G02013, doi:10.1029/2006JG000246.

Kahlown, M.A. and Iqbal, M. (1999) Impact of water logging and salinity on crop yield.Pak. Water and Power Dev. Authority.Public. No. 217, 98-109.

Kahlown, M.A., Ashraf, M., and Zia-ul-Haq (2005) Effect of shallow groundwater table on crop water requirements and crop yields. Agric. Water Manage. 76 (1), 24-35.

Kakar, M.A. (2000).Diagnostic study of water logging and salinity at Surizai Peshawar. M.Sc.(Hons). Thesis, submitted to NWFP Agric. Univ., Peshawar - Pakistan.

Kale, S. (2012) Impact of drained and un-drained soil conditions on water table depths, soil salinity and crop yields. African Journal of Agricultural Research, Vol. 7(19), 2935-2945. DOI: 10.5897/ AJAR12.101.

Kalita. P. K. and Kanwar, R. S. (1993) Effect of water table management practices on the fiansport of nitrate-N to shallow groundwater. Trans. ASAE 36,413-422.

Kandil, H.M., Skaggs, W.R., Abdel Dayem, S. and Aiad, Y. (1995) Drainmod-S Water management model for irrigated arid lands, crop yield and applications. Irrigation and Drainage Systems, 9, 239-258.

Kang, S., Zhang, F., Hu, X., Peter, J., and Zhang, L. (2001) Effects of shallow water table on capillary contribution, evapotranspiration, and crop coefficient of maize and winter wheat in a semi-arid region. Aust. J. Agric. Res. 52, 317-327.

Karimova, A., Simunekb, J., Hanjrac, M.A., Avliyakulovd, M. and Forkutsaea,I. (2014) Effects of the shallow water table on water use of winter wheat and ecosystem health: Implications for unlocking the potential of ground water in the Fergana Valley (Central Asia). Agricultural Water Management, 131,57- 69.

Khan, S., Hanjra, M.A. (2008) Sustainable land and water management policies and practices: a pathway to environmental sustainability in large irrigation systems. Land Degradation and Development, 19 (3):, 469-487.

Egypt. J. Soil. Sci. 58, No. 1 (2018) 
Lal, R. and Shukla M.K. (2004). Principles of soil physics, Marcel Dekker ;Taylor\& Francis, New York \& London.

Lesch, S., Rhoades, J. and Corwin, D. (2006) ESAP95 Version 2.01R, User Manual and Tutorial Guide, Riverside, California: U.S. Dept. of Agriculture, Agricultural Research Service.

Maas, E.V and Hoffman, G.J. (1977) Crop Salt Tolerance-Current Assessment. Journal of Irrigation and Drainage Engineering, 103 (IR2), 115-134.

Maynard, C.L., Lawrence, R.L., Nielsen, G.A. and Decker, G. (2006) Modeling vegetation amount using band wise regression and ecological site descriptions as an alternative to vegetation indices. GIS Science\& Remote Sensing, 43,1-14.

Metternicht, G. (2001) Assessing temporal and spatial changes of salinity using fuzzy logic, remote sensing and GIS.Foundations of an expert system. Ecological Modelling. 144: 163-179.

Mohamed, E. S., Belal, A., and Saleh, A. (2013) Assessment of land degradation east of the Nile Delta, Egypt using remote sensing and GIS techniques. Arabian Journal of Geosciences, 6 (8), 2843-2853.

Mohamed, E. S., Morgun, E. G., and Bothina, S. G. (2011) Assessment of soil salinity in the Eastern Nile Delta (Egypt) using geoinformation techniques. Moscow University Soil Science Bulletin, 66 (1), 11-14

Mortazavi, F., Mehraban, A. and Fanaei, H. R (2015) Influence of water stress and cultivar on some characteristic of soy bean. Biological Forum. An International Journal, 7(2), 859-861.

Nathanson, K., Lawn, R. J., DeJabrun, P. L. M. and Byth' D.E. (1984) Growth, nodulation and nitrogen accumulation by soybean in saturated soil culture. Field Crops Res. 8, 73-92.

Nosetto, M.D., Jobba'gy, E.G. , Jackson, R.B. and Sznaider, G.A. (2009) Reciprocal influence of crops and shallow ground water in sandy landscapes of the Inland Pampas. Field Crops Research, 113,138148.journal homepage: www.elsevier.com/locate/ fcr.

Patel, R., Prasher, S., Bonnell, R. andBoughton, R. (2002) Development of comprehensive soil salinity index. J. of Irrigation and Drainage EngineeringASCE. 128, 185-188.

Egypt. J. Soil. Sci. 58, No. 1 (2018)
Pelletier, V., Gallichand, J., Gumiere,S., Pepin, S. and Caron, J. (2015) Water Table Control for Increasing Yield and Saving Water in Cranberry Production. Sustainability, 2015, 7, :10602-10619; doi:10.3390/ su70810602.

Rasel, H. M., Hasan, M. R., Ahmed, B. and Miah, M. S. U. (2013) Investigation of soil and water salinity, its effect on crop production and adaptation strategy. International J. of Water Resources and Environmental Engineering, 5 (8), 475-481,Academic J.DOI 10.5897/ IJWREE2013.0400, ISSN2141-6613@ http://www. academicjournals.org/IJWREE.

Sarwar, T. (2002) Physiological response of soybean to shallow water table depths. Pakistan J. of Biol. Sci. 5, 1300-1308.

Semiz, G.D., Unlukara, A., Yurtseven, E., Suarez, D.L. and Telci, I. (2012) Salinity Impact on Yield, Water Use, Mineral and Essential Oil Content of Fennel Foeniculumvulgare Mill.). Journal of Agricultural Sciences, 18, 177-186.

Shermuhammadi, A. and Skaggs, R.W. (1984) Effect of soil surface conditions on infiltration for shallow water table soil. Transactions of the ASAE. 27(6).

Shimada, S., Kokubun, M. and Matsui, S. (1997) Effects of water table on physiological traits and yield of soybean: II. Effects of water table and rainfall on leaf water potential and photosynthesis. Jpn J. Crop Sci. 66, 108-117.

Singh, G., Williard, K. W. and Schoonover, J. E. (2016) Spatial Relation of Apparent Soil Electrical Conductivity with Crop Yields and Soil Properties at Different Topographic Positions in a Small Agricultural Watershed. Agronomy, 6 (4), 57; doi: 10.3390/agronomy 6040057.

Soppe, R.W.O. and Ayars, J.E. (2003) Characterizing groundwater use by safflower using lysimeters. Agric. Water Management, 60, 59-71.

Tan, C. S., Drury, C. F., Gaynor, J. D., van weSenbeeck, 1. and Soultani, M. (1995) Effect of water-table management and nitrogen supply on yield, plant growth and water use of corn in undisturbed soil columns. Can. J. Plant Sci. 76, 229-235. DOI: 10.4141/cjps96-042.

Villa-Castorena, M., Ulery, A.L., Catalán-Valencia, E.A. and Remmenga, M.D. (2003) Salinity and nitrogen rate effects on the growth and yield of Chilli Pepper plants. Soil Sci. Soc. Am. J. 37, 17811789.

Wang, R., Kang, Y., Wan, S., Hu, W., Liu, S., Jiang, S. 
and Liu, S. (2012) Influence of different amounts of irrigation water on salt leaching and cotton growth under drip irrigation in an arid and saline area. Agric. Water Manag., 110, 109-117.

Wesseling, J. (1974) Crop Growth in Wet Soils. Drainage for Agriculture, J. van Schilfgaard (Ed.) 7-37. Madison, WI: ASA.

White, K. (1997) Remote Sensing. Progress in Physical Geography, 21, 297-305.

Williamson, R E. (1968) Effect of water table depth and method of watering on yield of string bcans. Agron. J. 60, 242-244.
Wu, J., Vincent, B., Yang, J., Bouarfa, S. and Vidal, A. (2008) Remote Sensing Monitoring of Changes in Soil Salinity: A Case Study in Inner Mongolia, China. Sensors, 8, 7035-7049; DOI: 10.3 390/ s8117035.

Wu, Y.K., Yang, J.S. and Li X.M. (2009) Study on spatial variability of soil salinity based on spectral indices and EM38 readings. Spectroscopy and Spectral Analysis, 29, 1023-1027.

(Received:25 /10 / 2017 ; accepted:16 / 1 / 2018 )

\section{تقييم تأثير الماء الأرضى الضحل على ملوحة التربة ومحصول الكتلة الحيوية لنباتات شمال

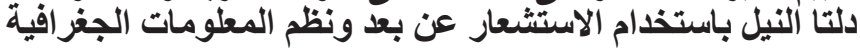 \\ مجاهد محمد عامر ، هثام محمود ابو السعود ،السعيد حماد عمرومدحت جابر زغدان

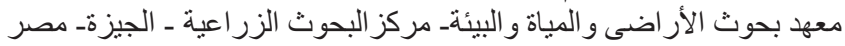

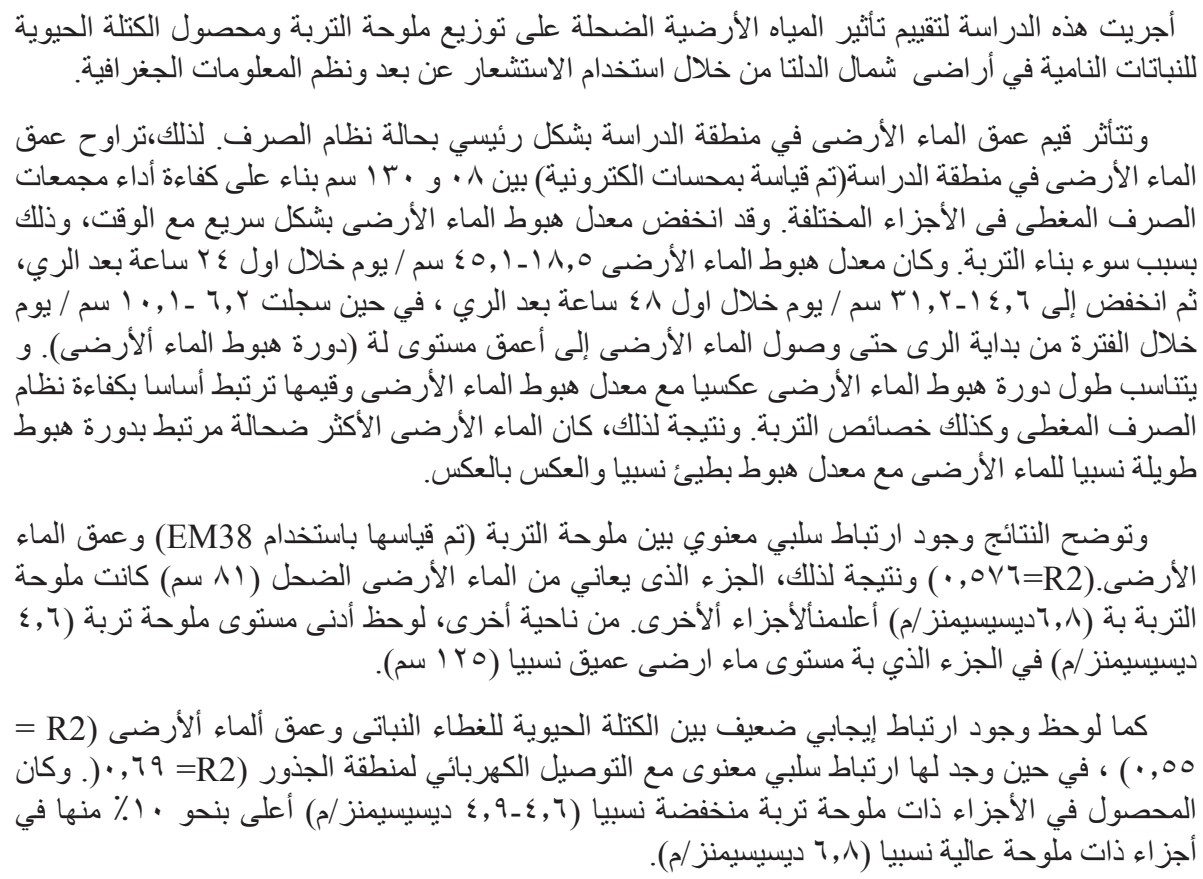

